\title{
Estimating growth in haddock larvae Melanogrammus aeglefinus from RNA:DNA ratios and water temperature
}

\author{
Elaine M. Caldarone* \\ National Oceanic and Atmospheric Administration, National Marine Fisheries Service, Northeast Fisheries Science Center, \\ Narragansett Laboratory, 28 Tarzwell Drive, Narragansett, Rhode Island 02882-1152, USA
}

\begin{abstract}
Five biochemically based variables (RNA, DNA, protein content, RNA:DNA [R:D] ratio, protein:DNA [pro:DNA] ratio) were evaluated as potential indirect measures of growth in larval haddock Melanogrammus aeglefinus. Larvae were reared in the laboratory from hatch to $47 \mathrm{~d}$ post-hatch under temperature $(T)$-controlled conditions $\left(6,8\right.$, and $\left.10^{\circ} \mathrm{C}\right)$ and, to produce a variety of growth rates, were starved or reared at 1 of 3 prey levels. The nucleic acid content of the larvae was measured with a spectrofluorometric microplate assay, and the protein-specific growth rate $\left(\mathrm{SGR} \% \mathrm{~d}^{-1}\right)$ was estimated from the difference in mean protein content between consecutive sampling intervals. Larval haddock growth rate was best described by R:D or pro:DNA ratios. The growth models developed were: $\mathrm{SGR}=4.61 \mathrm{R}: \mathrm{D}+1.18 T-17.31\left(\mathrm{R}^{2}=0.52\right)$ and $\mathrm{SGR}=0.92$ pro:DNA $+1.10 T-24.97\left(\mathrm{R}^{2}=\right.$ 0.52). These models can be used to estimate recent growth of larval haddock collected from both the laboratory and field. A combined haddock/Atlantic cod Gadus morhua growth model was calculated as: $\mathrm{SGR}=4.67 \mathrm{R}: \mathrm{D}+0.96 T-15.30\left(\mathrm{R}^{2}=0.45\right)$. This model will be used to estimate recent growth of haddock and cod larvae collected during a multi-year field sampling effort on Georges Bank.
\end{abstract}

KEY WORDS: RNA:DNA ratio $\cdot$ Growth $\cdot$ Haddock $\cdot$ Larvae $\cdot$ Nutritional condition $\cdot$ Nucleic acids Fluorometric microplate assay $\cdot$ Temperature effects

\section{INTRODUCTION}

Researchers have used a variety of morphometric, histological, and biochemical indices to measure recent growth and nutritional condition of marine fish larvae (see review by Ferron \& Leggett 1994). Among the more widely used biochemical indices are those based on nucleic acids, such as RNA:DNA (R:D), RNA:mg tissue, and protein:DNA (pro:DNA) ratios (e.g. Buckley \& Lough 1987, Folkvord et al. 1996, Rooker \& Holt 1996, Chícharo 1998, Heyer et al. 2001, Buckley et al. 2004). The physiological basis for these indices is that larval fish grow rapidly, increasing their body muscle mass through an increase in protein synthesis (Houlihan et al. 1995). RNAs are essential for the biosynthesis of proteins, and their number and activity changes in response to the demand for protein synthesis (Young 1970, Henshaw et al. 1971). DNA levels in a cell remain fairly constant, even during starvation, and can serve to normalize the measured RNA (Bulow 1987, Buckley et al. 1999). An increase or decrease in the R:D or RNA:mg tissue ratios at a given temperature would, therefore, indicate a concomitant change in protein synthesis and growth rate.

Relative changes in the R:D ratio have been used to describe the nutritional condition of larvae (e.g. Canino et al. 1991, Chícharo 1997, Clemmesen et al. 1997, Rooker et al. 1997). When properly calibrated with laboratory experiments, the R:D ratio can also be used to estimate instantaneous growth rates (Buckley 1982, 1984, Folkvord et al. 1996, Caldarone et al. 2003, 
Peck et al. 2003). Growth-rate estimation of fieldcaught fish is a powerful tool for evaluating the survival potential of an individual and for identifying environmental variables which may affect recruitment success (Houde 1987, Meekan \& Fortier 1996). One advantage of a nucleic-acid-based growth estimate is its rapid response time; the R:D ratio in post yolk-sac larvae can reflect changes in growth rates and nutritional condition over time periods ( 1 to $4 \mathrm{~d}$ ) where it would be difficult to detect changes in mass or length (Buckley 1980, Wright \& Martin 1985, Clemmesen 1987). The capability to measure growth over similar temporal scales to environmental conditions should help to identify biotic and abiotic factors that regulate larval growth.

Because the biosynthesis of proteins is a chemical reaction, and rates of chemical reactions are controlled by temperature, any index containing RNA should account for temperature-dependent changes in reaction rates. Researchers have observed that adding a temperature term improves the linear relation between the R:D ratio and the growth rate in a variety of laboratory-reared larval and juvenile fish (Buckley 1982, 1984, Folkvord et al. 1996, Caldarone et al. 2003, Peck et al. 2003). To date, all published growth rate-R:D-temperature models are speciesspecific except for Buckley's (1984), which is based on data from 8 species of temperate marine fishes. His model may not, however, be universally applicable to all species and stages, and no model specific for larval haddock Melanogrammus aeglefinus yet exists. Additionally, Buckley's model is based on nucleic acids measured with an ultraviolet absorption assay, while most contemporary methods use fluorometric dyes. Due to procedural differences, the use of any of the published R:D-based growth equations requires that either the same analytical methods and standards be used, or that the nucleic-acid analysis methods be intercalibrated (Caldarone \& Buckley 1991, Clemmesen 1993, Buckley et al. 1999, Caldarone et al. 2001, Esteves et al. 2000). Alternatively, a model can be derived in the laboratory from experiments conducted under temperature-controlled conditions with the species, analytical method, and standards of choice.

For this study, nucleic acids were analyzed with a microplate spectrofluorometric assay. The objectives were (1) to determine the best predictor of larval haddock growth rate (measured as the change in whole body protein $\mathrm{d}^{-1}$ ) from temperature and a variety of potential biochemical indices (RNA, DNA, protein content, R:D, pro:DNA), and (2) to develop a growth model from the indices to estimate short-term growth rates of haddock larvae collected from both the laboratory and the field.

\section{MATERIALS AND METHODS}

Growth trial. Larvae used in the experiment were spawned by the NOAA/NMFS Narragansett Laboratory haddock broodstock. The broodstock, which consisted of $\sim 34$ fish caught by longline on the western side of Great South Channel, MA, USA, were maintained in a large community tank for 1 to $5 \mathrm{yr}$ and allowed to spawn naturally.

An experiment similar in design to one for Atlantic cod Gadus morhua described in Caldarone et al. (2003) was conducted during April and May 2002. Haddock larvae were reared for a maximum of $7 \mathrm{wk}$ in eight 381 black all-glass rectangular aquaria in each of 3 identical constant temperature rooms (24 tanks in total). To incorporate the range of temperatures routinely encountered by larval haddock on Georges Bank in April through June, nominal room temperatures were set at 6,8 , and $10^{\circ} \mathrm{C}$ (Walsh et al.1987). To produce a range of growth rates at each temperature, larvae (in duplicate tanks) were either starved or fed at 1 of 3 prey levels.

On 5 April 2002, $150 \mathrm{ml}$ fertilized haddock eggs ( 42000 eggs) were collected and placed in a $200 \mathrm{l}$ round fiberglass tank supplied with ambient seawater $\left(\sim 8.7^{\circ} \mathrm{C}\right)$. To increase the potential for hatching success, the eggs were allowed to develop for $7 \mathrm{~d}$ before being distributed to the $38 \mathrm{l}$ aquaria, and only those embryos floating in the top portion of the water column were used in the experiment. The stocked aquaria were placed in 3 constant temperature rooms and allowed to equilibrate over a $24 \mathrm{~h}$ period to the final rearing temperatures. Aquaria were stocked at the embryo stage to allow the embryos/larvae to acclimate to the experimental temperatures for at least $4 \mathrm{~d}$ prior to the first sampling day (2 to $3 \mathrm{~d}$ post-hatch [dph]).

Aquaria stocking densities were selected to balance the total number of embryos available with anticipated sampling needs. To increase the probability of obtaining detectable growth, sampling schedules were initially based on degree-days (temperature $\left({ }^{\circ} \mathrm{C}\right) \times$ time interval (d), 40 to $42^{\circ} \mathrm{d}$ ). Larvae reared at $6^{\circ} \mathrm{C}$ were sampled every $7 \mathrm{~d}$ starting $2 \mathrm{dph}$; larvae at $8^{\circ} \mathrm{C}$ were sampled every $5 \mathrm{~d}$ for the first 3 wk starting at $3 \mathrm{dph}$, then once a week for the remainder of the experiment; larvae at $10^{\circ} \mathrm{C}$ were sampled every $4 \mathrm{~d}$ for the first $24 \mathrm{~d}$ starting at $3 \mathrm{dph}$, then every $8 \mathrm{~d}$ until the experiment was concluded. The fed treatment tanks at the higher temperatures were stocked with more embryos to compensate for higher sampling mortalities due to increased sampling frequencies. The starved treatment tanks at the lowest temperature were stocked with higher numbers of embryos in anticipation of an extended sampling period. Embryos were distributed to the tanks volumetrically yielding stocking densities of approximately 1400, 1680, and 2240 embryos per 
aquaria for the fed groups, and 840, 560, and 560 embryos for the starved groups at 6,8 , and $10^{\circ} \mathrm{C}$, respectively. Identical stocking densities were not necessary since the experiment was designed to test the relation between the growth rate of the larvae sampled and the biochemical indices measured, not the relation between growth rate and food levels.

Streptomycin (24 $\left.\mathrm{mg} \mathrm{l}^{-1}\right)$ and penicillin (17.5 $\mathrm{mg} \mathrm{l}^{-1}$ ) were added to each tank to control bacterial growth (Peck et al. 2004). Tanks were gently aerated and the water was not exchanged until $50 \%$ hatch was observed 12,11 , and $9 \mathrm{~d}$ after fertilization, at 6,8 , and $10^{\circ} \mathrm{C}$, respectively. Each aquarium was then continuously supplied with seawater at a rate averaging $54 \mathrm{ml} \mathrm{min}^{-1}$, permitting a complete water exchange $\sim 2.5 \mathrm{~d}^{-1}$.

Prey was added to the tanks twice daily, once in the morning before 10:00 $\mathrm{h}$ and again between 16:00 and 17:00 h. For the first $28 \mathrm{dph}$, all groups of fed larvae received a mixture of rotifers Brachionus plicatilis and wild zooplankton. Rotifers were reared using culture and enrichment diets specifically formulated for rotifers (Selco 3000 and DHA Selco, Inve Aquaculture $^{1}$ ). For optimal enrichment, additional DHA was added to the rotifer culture $6 \mathrm{~h}$ prior to feeding. Plankton (primarily copepod nauplii and copepodites) were collected 5 d per week from Narragansett Bay and sieved by size (50 to $210 \mu \mathrm{m}$ ) before being fed. Nominal concentrations of rotifers added to the tanks when plankton were not available were 2.5, 5.0, and 8.5 rotifers $\mathrm{ml}^{-1} \mathrm{~d}^{-1}$ at the low, medium, and high food levels, respectively. On days when wild plankton were available, plankton were substituted for rotifers at a rate of 1:5 ( 1 plankter $=5$ rotifers). The average energy content of an individual copepod nauplii and copepodite is approximately $1.6 \times$ and $11.4 \times$ respectively, the average energy content of a rotifer (Holm et al. 1991). Screens on the outflow of the aquaria were sized to retain the larvae while allowing the rotifers and plankton to pass through (0.8 mm mesh). Random sampling in the morning revealed little hold-over of prey from the previous day.

After $28 \mathrm{dph}$, wild plankton became unavailable and the larvae were fed only rotifers supplemented with brine shrimp (Artemia sp.) nauplii. The brine shrimp were enriched for 12 to $24 \mathrm{~h}$ with a lipid/vitamin mixture (Super-Selco, Inve Aquaculture) prior to feeding, and were fed at rates of 0.13 and $0.25 \mathrm{ml}^{-1}$ at the medium and high food treatments, respectively. Artemia were not added to low food treatment tanks.

Water temperatures were monitored daily and the water in the aquaria was gently aerated to evenly disperse the prey. Water flow-rates were checked and

${ }^{1}$ Mention of trade names does not imply endorsement by the NOAA/NMFS adjusted throughout the experiment, and the bottoms of the tanks were siphoned as needed.

Ammonia concentrations in the aquaria were normally undetectable, although occasionally a seawater inlet tube would clog and ammonia levels would rise to $0.4 \mathrm{mg} \mathrm{l}^{-1}$. Salinities ranged from 31 to $33 \mathrm{ppt}$ and the photoirradiance at the water surface was 2.3 to $4.0 \mu \mathrm{mol} \mathrm{s}{ }^{-1} \mathrm{~m}^{-2}$ ( 184 to $\left.319 \mathrm{~lx}\right)$ during a $14 \mathrm{~h}$ daylight photoperiod. Downing \& Litvak (2001) have reported that a light intensity between 1.7 and $18 \mu \mathrm{mol} \mathrm{s} \mathrm{s}^{-1} \mathrm{~m}^{-2}$ is optimum for haddock feeding success.

Biochemical variables. Initially, samples consisted of 3 groups of 10 larvae collected from each tank on each sampling date. When the number of survivors in a tank had substantially diminished due to sampling and natural mortality, the number of individuals per group was reduced in order to prolong the sampling schedule. Of the 435 samples analyzed, $52 \%$ contained 10 individuals, $44 \%$ contained 5 to 9 individuals, and the remaining $4 \%$ contained a minimum of 2 groups of 4 individuals. Samples were immediately frozen in a cryovial and stored at $-80^{\circ} \mathrm{C}$. On the day of analysis, samples were extracted in a tris-EDTA buffered detergent ( $1 \% \mathrm{~N}$-lauroylsarcosine) to disrupt the cells, dissociate the nucleoproteins from the nucleic acids, and allow for improved binding of fluorescent dye to the nucleic acids. Aliquots from the resulting extract were measured for RNA, DNA, and protein content. The nucleic acids were determined with a 1-dye (ethidium bromide)/1-enzyme (RNase) 96-well microplate fluorometric assay which is described in detail in Caldarone et al. (2001). Briefly, the standards and N-lauroylsarcosine extracted samples were mixed (in duplicate) with ethidium bromide in a 96-well microplate, and the total nucleic acid fluorescence was recorded. RNA was then enzymatically digested by adding RNase and the plate was read a second time. RNA concentrations were calculated from the difference in fluorescence between the first and second reading. To measure residual fluorescence, a subset of RNase-treated samples was also treated with DNase. The addition of the second enzyme did not alter the fluorescence; therefore, for all the samples, the entire fluorescence from the second reading (RNase-treated only) was attributed to DNA. Standard calibration curves were constructed by serially diluting commercial preparations of $18 \mathrm{~S}-$ and 28S-rRNA (Sigma R-0889) and ultra-pure highlypolymerized calf thymus DNA (Sigma D-4764). rRNA standards ranged from 1 to $11 \mu \mathrm{g} \mathrm{ml}^{-1}$; DNA standards ranged from 0.3 to $3.7 \mu \mathrm{g} \mathrm{ml}^{-1}$. The average ratio of the slope of the DNA standards to the slope of the RNA standards was 2.7. Samples were scanned with a BioTek FL500 fluorescence microplate reader with excitation and emission wavelengths set at 530 and $590 \mathrm{~nm}$, respectively. 
Larval protein content was determined on duplicate aliquots of extract with a bicinchoninic colorimetric assay (Smith et al. 1985) adapted to a 96-well microplate format. Samples or standards plus reagents were incubated at $60^{\circ} \mathrm{C}$ for $1 \mathrm{~h}$ to achieve a stable endpoint. A standard calibration curve was constructed by serially diluting bovine serum albumin.

A control homogenate was prepared by homogenizing 50 cod larvae $(21 \mathrm{dph})$ in $3.75 \mathrm{ml}$ of distilled deionized water with an Ultra-turrax tissumizer equipped with a micro attachment. Aliquots $(75 \mu \mathrm{l})$ of homogenate were stored frozen at $-80^{\circ} \mathrm{C}$ and, as a quality control measure, 1 aliquot was processed during each nucleic-acid assay and protein assay to verify the accuracy of the runs.

Larval growth and mortality. Instantaneous protein growth coefficients $\left(G_{i} \mathrm{~d}^{-1}\right)$ were calculated from the difference in mean protein content from one sample date $\left(t_{2}\right)$ to the previous one $\left(t_{1}\right)$ with the formula:

$$
G_{i}=\left(\ln P_{t_{2}}-\ln P_{t_{1}}\right) /\left(t_{2}-t_{1}\right)
$$

where $P$ is the mean protein content $(\mu \mathrm{g})$ of larvae from 1 tank (mean of 2 to 3 groups of 4 to 10 individuals) at time $t$, the age in days. Growth rates were hindcast, that is, the growth rate was calculated over the interval immediately preceding the R:D sampling. Protein specific growth rates $\left(\mathrm{SGR}, \% \mathrm{~d}^{-1}\right)$ were calculated from the instantaneous protein growth coefficients with the formula (Sutcliffe 1970):

$$
\mathrm{SGR}=100\left(\mathrm{e}^{G_{i}}-1\right)
$$

Statistical analyses. Using data from each sample aged $>8 \mathrm{dph}$, a Pearson product moment correlation matrix was computed to test the strength of the relationship between the variables measured (RNA content, DNA content, protein content, age, water temperature, R:D, pro:DNA, SGR).

A model to predict SGR from the biochemical variables measured was built using multiple linear regression analysis with a step-wise selection process. Independent variables tested were: RNA content, DNA content, protein content, water temperature, and either R:D or pro:DNA. Input values included individual tank means of measured variables from each sampling day, mean tank temperature between the sampling days, and the corresponding SGR calculated from the equation listed above. Variables had to meet a 0.10 significance level for entry into the model.

SGR was also calculated using different time intervals to determine whether the R:D-temperature relation could be used to forecast growth rates, and to determine what effect increasing the growth interval had on the relation. The relations examined included (1) a growth forecast to the next consecutive sampling period after the R:D sample (SGR calculated from $t_{2}$ to $\left.t_{3}\right)$, (2) a forecast/hindcast which encompassed the growth interval immediately preceding the R:D sample to the next consecutive sample after the R:D sample (SGR calculated from $t_{1}$ to $t_{3}$ ), (3) a hindcast encompassing a growth interval starting 2 sampling dates previous to the R:D sample (SGR calculated from $t_{0}$ to $t_{2}$ ). Temperature data used in the regression models were mean tank temperatures between the specific time intervals investigated.

In Caldarone et al. (2003), a growth model based on the R:D ratio and water temperature was developed for cod. In order to determine whether a single model could apply equally well to both haddock and cod, or whether 2 separate (species-specific) growth models were necessary, data from a combined haddock/cod data set were analyzed by multiple linear regression with a stepwise selection process. The data set included all of the data from this study plus cod data from the first cod trial and starved fish from the second cod trial as reported in Caldarone et al. (2003). The independent variables tested were the R:D ratio, temperature, species, the interaction of species with the R:D ratio, and the interaction of species with temperature. Variables had to meet a 0.10 significance level for entry into the model.

All statistical analyses were carried out using SAS software version 8.02 (SAS Institute 1999).

Table 1. Melanogrammus aeglefinus. Pearson product moment correlation (r) of variables measured in haddock samples containing 4 to 10 larvae each (age $>8 \mathrm{dph}$ ). R:D: RNA:DNA; Pro:DNA: protein:DNA; SGR: protein-specific growth rate $\left(\% \mathrm{~d}^{-1}\right.$ )

\begin{tabular}{|c|c|c|c|c|c|c|c|}
\hline Variable & RNA & Protein & Age & Temperature & $\mathrm{R}: \mathrm{D}$ & Pro:DNA & SGR \\
\hline DNA $\left(\mu \mathrm{g}\right.$ larva $\left.^{-1}\right)$ & $0.97^{* * *}$ & $0.97^{* * *}$ & $0.74^{* * *}$ & $0.36^{* * *}$ & $0.37^{* * *}$ & $0.32^{* * *}$ & $0.38^{* * *}$ \\
\hline RNA ( $\mu$ g larva $\left.{ }^{-1}\right)$ & & $0.99^{* * *}$ & $0.66^{* * *}$ & $0.32^{* * *}$ & $0.46^{* * *}$ & $0.41^{* * *}$ & $0.42^{* * *}$ \\
\hline Protein $\left(\mu \mathrm{g}\right.$ larva $\left.{ }^{-1}\right)$ & & & $0.68^{* * *}$ & $0.32^{* * *}$ & $0.42^{* * * *}$ & $0.43^{* * *}$ & $0.41^{* * *}$ \\
\hline Age (dph) & & & & $0.20^{* *}$ & $0.31^{* * *}$ & $0.37^{* * *}$ & $0.19^{* *}$ \\
\hline Temperature $\left({ }^{\circ} \mathrm{C}\right)$ & & & & & $0.12^{*}$ & $0.14^{*}$ & $0.45^{* * *}$ \\
\hline $\mathrm{R}: \mathrm{D}$ & & & & & & $0.74^{* * *}$ & $0.57^{* * *}$ \\
\hline Pro:DNA & & & & & & & $0.50^{* * *}$ \\
\hline
\end{tabular}
calculated over 4 to 8 d sampling interval; dph: days post-hatch. $\mathrm{n}=307 .{ }^{*} \mathrm{p}<0.05 ;{ }^{* *} \mathrm{p}<0.001 ;{ }^{* * *} \mathrm{p}<0.0001$ 


\section{RESULTS}

\section{Variable correlations}

Results of Pearson product moment correlation analysis indicated that all the measures of size (DNA, RNA, protein content) were significantly positively correlated $(\mathrm{p}<0.0001)$ (Table 1). The remaining variables were also positively correlated at the $\mathrm{p}<0.0001$ or $\mathrm{p}<0.001$ levels except for temperature versus the R:D ratio and temperature versus the pro:DNA ratio $(p<0.05)$. After $10 \mathrm{dph}$, the fish in all the fed treatments grew larger with increasing age, temperature, and prey level, as indicated by an overall increase in DNA, RNA, and protein content ( $\mu \mathrm{g}$ larva $^{-1}$, Figs. 1 to 3 ).

\section{Trends in biochemical variables with time, temperature, and feeding level}

In the starved groups, mean DNA content ( $\mu \mathrm{g}$ larva $^{-1}$ ) increased from hatch until $~ 9 \mathrm{dph}$, then decreased slightly until complete mortality was reached at 16,13 , and $11 \mathrm{dph}$ at 6,8 , and $10^{\circ} \mathrm{C}$, respectively (Fig. 1). During this time, mean RNA and protein content of the starved fish continually decreased $(\mu \mathrm{g}$ larva $^{-1}$, Figs. $2 \& 3$ ). The combination of these changes resulted in a large decrease in the R:D and pro:DNA ratios of the starved groups from hatch until complete mortality was reached (Figs. 4 \& 5). SGRs of starved fish during this time were negative or near zero (Fig. 6).

During the first sampling period ( 2 to $3 \mathrm{dph}$ ), the R:D ratio of all the fish averaged 3.7 (range 2.9 to 4.5 ), the pro:DNA ratio averaged 26.6 (range: 18.4 to 37.1 ), and protein concentration averaged $35.8 \mu \mathrm{g}$ protein larva ${ }^{-1}$ (range: 25.8 to 41.3 ). Just prior to complete mortality, the R:D ratio values of the starved fish reached a minimum of $1.7,1.5$, and 1.4 ; the pro:DNA ratio values reached a minimum of 19.0,19.4, and 17.6; and protein concentrations reached a minimum of 25.4, 25.7, and $24.1 \mu \mathrm{g}$ larva $^{-1}$ at 6,8 , and $10^{\circ} \mathrm{C}$ respectively, resulting in a total decrease in protein of 27,25 , and $36 \%$.

In the fed groups, mean DNA content increased with increasing age and temperature at all 3 prey levels (Fig. 1). Mean RNA content remained constant or decreased slightly between the first ( 2 to $3 \mathrm{dph}$ ) and second sampling periods $(9,8$, and $7 \mathrm{dph}$ at 6 , 8 , and $10^{\circ} \mathrm{C}$, respectively), followed by a general increase with increasing age and temperature (Fig. 2). After remaining fairly constant for the first $10 \mathrm{dph}$, mean protein content increased for the remainder of the experiment at all temperatures and prey levels (Fig. 3). The R:D ratio of the fed fish initially decreased reaching a minimum level at 15,11 ,
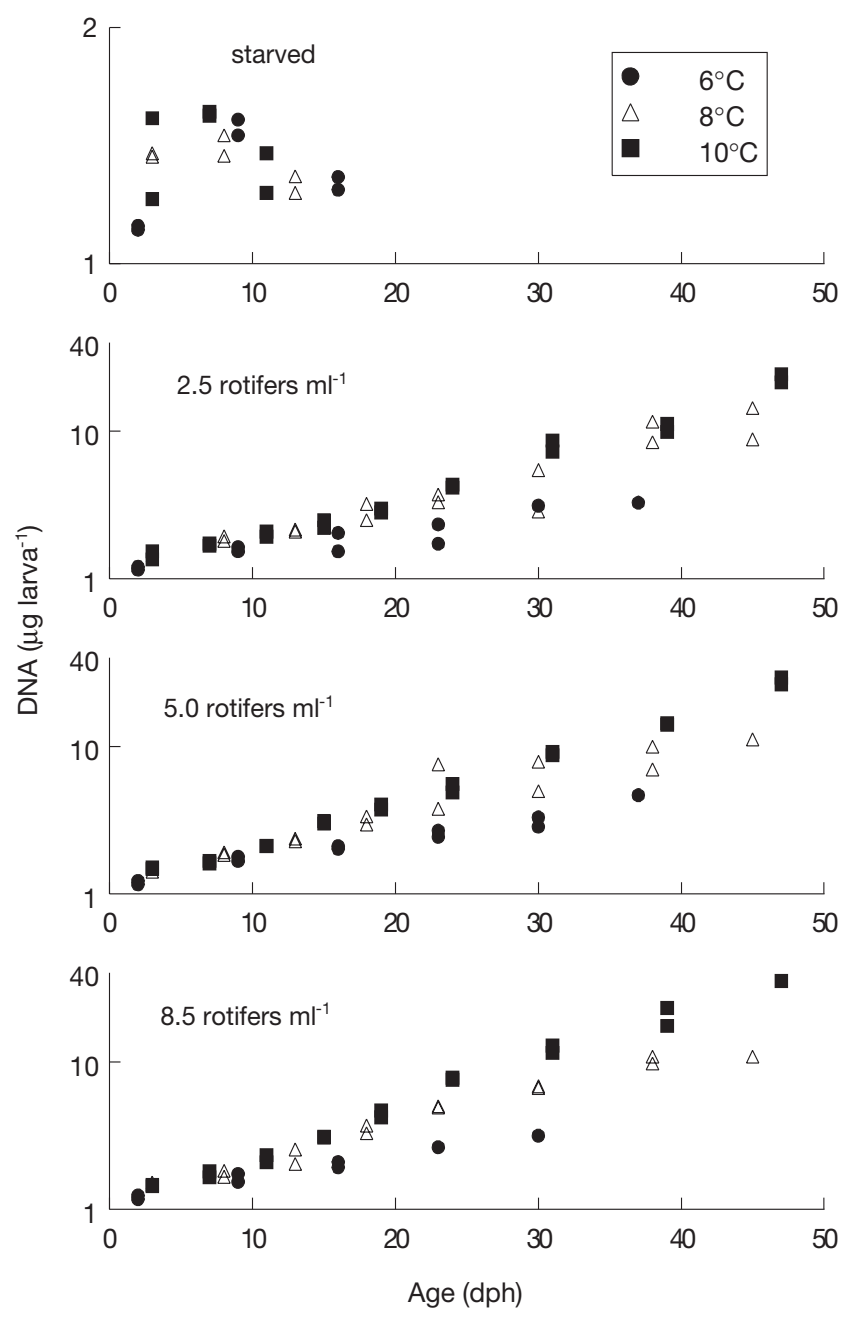

Fig. 1. Melanogrammus aeglefinus. Age-specific DNA content $\left(\mu \mathrm{g} \mathrm{larva} \mathrm{l}^{-1}\right)$ of haddock larvae at each combination of prey concentration and temperature. Each data-point represents a tank mean ( 2 to 3 samples of 4 to 10 larvae). The $y$-axis for the fed groups are log scale. dph: days post-hatch

and $10 \mathrm{dph}$ at 6,8 , and $10^{\circ} \mathrm{C}$, respectively. The timing of these minimum levels generally coincided with the timing of complete mortality in the starved groups at each respective temperature (Fig. 4). The pro:DNA ratio of the fed fish also initially decreased, reaching minimum levels at 16,8 , and $8 \mathrm{dph}$ at 6,8 , and $10^{\circ} \mathrm{C}$, respectively (Fig. 5). The R:D and pro:DNA ratios of survivors then increased over the next $2 \mathrm{wk}$ and remained relatively stable for the remainder of the experiment. During the first growth sampling interval ( 2 to 9,3 to 8 , and 3 to $7 \mathrm{dph}$ at 6,8 , and $10^{\circ} \mathrm{C}$, respectively), mean SGRs of fed fish were low and similar to starved fish. SGRs then increased with increasing age and temperature, with some variability between $25 \mathrm{dph}$ and the conclusion of the experiment (Fig. 6). 

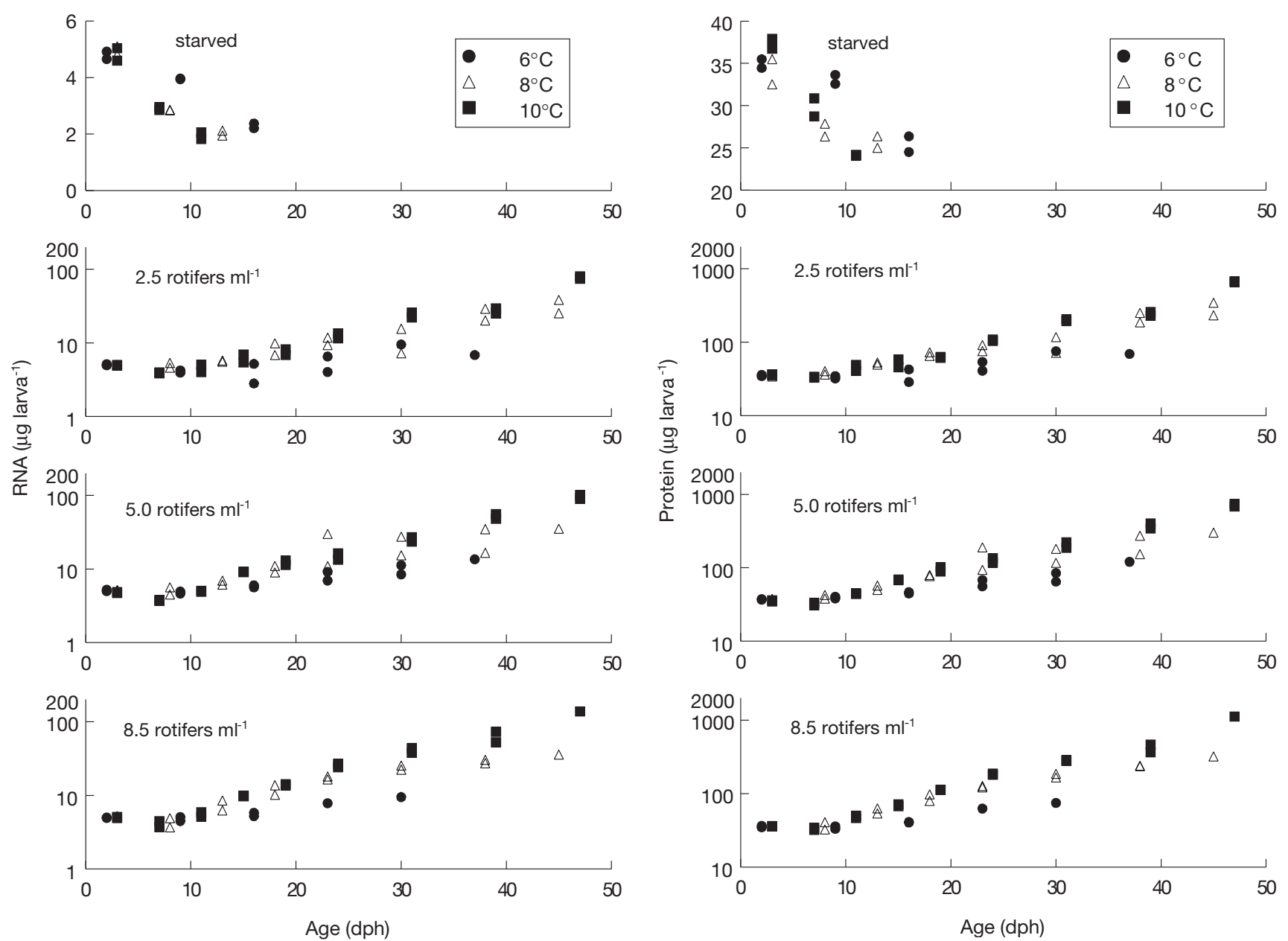

Fig. 2. Melanogrammus aeglefinus. Age-specific RNA content $\left(\mu \mathrm{g}\right.$ larva ${ }^{-1}$ ) of haddock larvae at each combination of prey concentration and temperature. Further details as in Fig. 1

Fig. 3. Melanogrammus aeglefinus. Age-specific protein content ( $\mu \mathrm{g} \mathrm{larva}^{-1}$ ) of haddock larvae at each combination of prey concentration and temperature. Further details as in Fig. 1

\section{Model development}

When plotted against age, residuals from preliminary regression analyses revealed a pattern of consistently negative values from hatch through $8 \mathrm{dph}$ (i.e. predicted growth higher than observed); therefore, only fish older than $8 \mathrm{dph}$ were included in the final regressions. Of the 5 biochemical indices examined, the R:D and pro:DNA ratios were the most highly correlated with growth $\left(t_{1}\right.$ to $t_{2}$ ) (Table 1), and were the first variables to enter the models (Table 2: Eqs. 1 \& 2). Because the 2 ratios were highly correlated with each other ( $\mathrm{r}=0.74$, Table 1$), 2$ separate models were developed. Temperature was the next variable to enter both models (Table 2: Eqs. 3 to 5); no other biochemical variable met the significance level for entry. Residuals from either growth model (Eqs. 3 \& 4) versus any of the size-related biochemical variables (RNA, DNA, protein content) were normally distributed.

The relationship between the R:D or pro:DNA ratios and SGR within each rearing temperature are illustrated in Figs. 7 \& 8. For visual clarity, all the data from a tank were averaged to create a single grand mean for each tank. The regression lines were predicted from Eqs. (3) or (4) by substituting 6, 8, or $10^{\circ} \mathrm{C}$ as the temperature term. Within a single rearing temperature, the R:D or pro:DNA ratios could distinguish between fast- and slow-growing fish. However, at constant SGRs, the R:D and pro:DNA ratios were inversely related to temperature (Figs. $7 \&$ 8, Table 2: Eqs. 3 \& 4).

Of the SGRs examined over the different time intervals, all SGR-R:D-temperature relations were significant at the $\mathrm{p}<0.001$ level and yielded (1) an $\mathrm{R}^{2}=0.31$ for growth forecast to the next consecutive sampling period, (2) an $\mathrm{R}^{2}=0.52$ for the forecast/hindcast growth estimate, and (3) an $\mathrm{R}^{2}=0.68$ for the hindcast growth 

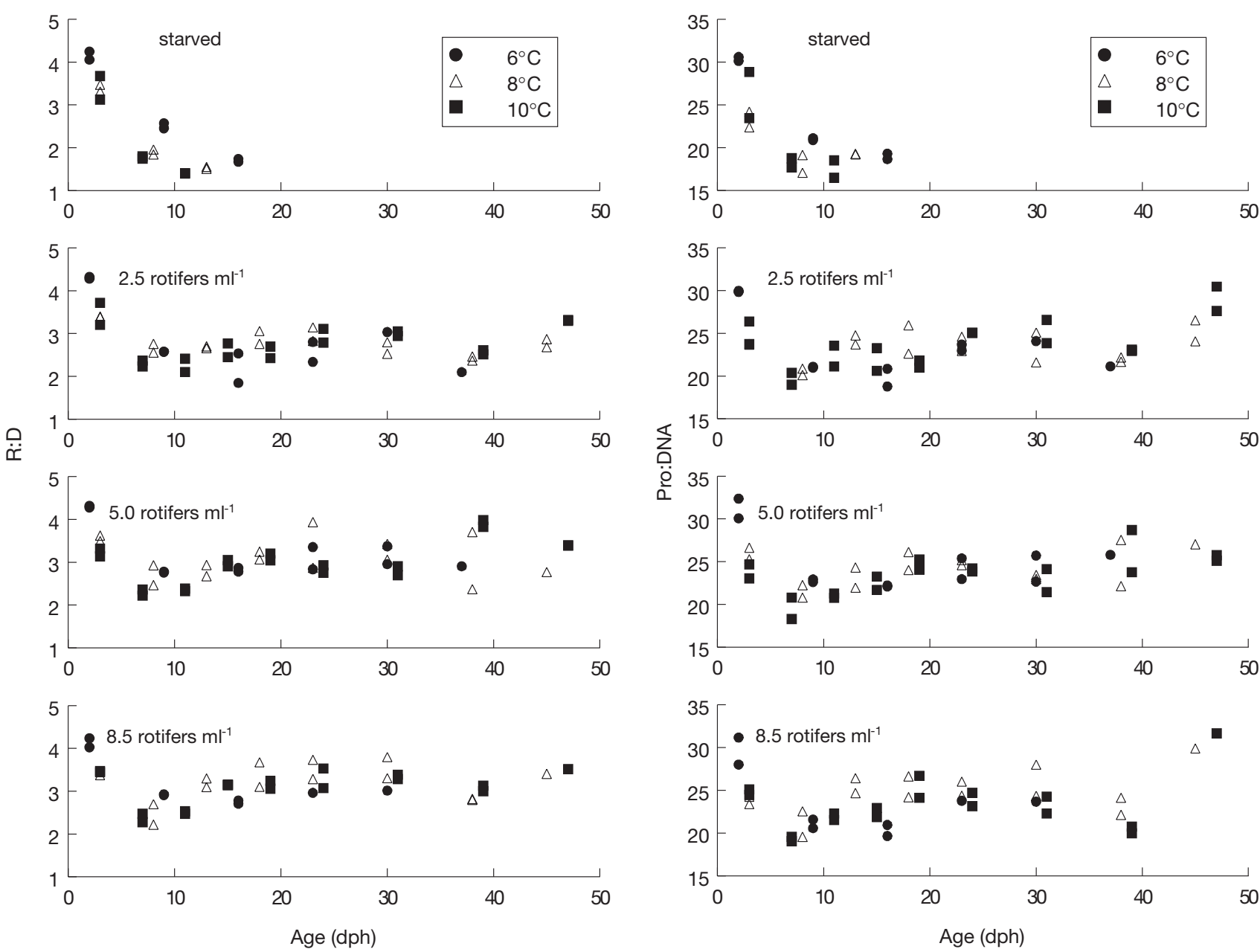

Fig. 4. Melanogrammus aeglefinus. Age-specific RNA:DNA ratio (R:D) of haddock larvae at each combination of prey concentration and temperature. Each data-point represents a tank mean ( 2 to 3 samples of 4 to 10 larvae). dph: days posthatch

Fig. 5. Melanogrammus aeglefinus. Age-specific protein: DNA ratio (pro:DNA) of haddock larvae at each combination of prey concentration and temperature. Further details as in Fig. 4

Table 2. Melanogrammus aeglefinus and Gadus morhua. Eqs. (1) to (5): Equations for growth of haddock larvae (age $>8$ dph). Variables listed met a 0.10 significance level for entry into the model. Input values are individual tank means of measured variables from each sampling day, mean tank temperature between sampling days, and corresponding protein-specific growth rate $\left(\mathrm{SGR}, \% \mathrm{~d}^{-1}\right)$ or instantaneous growth coefficient $\left(G_{i} \mathrm{~d}^{-1}\right)$. Either SGR or $G_{i}$ is the dependent variable; RNA/DNA, protein/DNA, and temperature are independent variables. All regressions are significant at the $p<0.0001$ level. Eqs. (6) \& (7) contain haddock data from this study plus cod data from Caldarone et al. (2003)

\begin{tabular}{|lccclr|}
\hline Eq. no. & $y$ & $x_{1}$ & $x_{2}$ & Equation & $\mathrm{R}^{2}$ \\
\hline Haddock & & & & $\mathrm{n}$ \\
1 & SGR & RNA/DNA & & $y=5.21 x_{1}-9.40$ & 0.32 \\
2 & SGR & Protein/DNA & & $y=1.07 x_{1}-19.50$ & 102 \\
3 & SGR & RNA/DNA & Temperature & $y=4.61 x_{1}+1.18 x_{2}-17.31$ & 102 \\
4 & SGR & Protein/DNA & Temperature & $y=0.92 x_{1}+1.10 x_{2}-24.97$ & 0.52 \\
5 & $G_{i}$ & RNA/DNA & Temperature & $y=0.0443 x_{1}+0.0111 x_{2}-0.1653$ & 0.52 \\
Haddock and cod combined & & & & 102 \\
6 & SGR & RNA/DNA & Temperature & $y=4.67 x_{1}+0.96 x_{2}-15.30$ & 102 \\
7 & $G_{i}$ & RNA/DNA & Temperature & $y=0.0450 x_{1}+0.0090 x_{2}-0.1466$ & 0.45 \\
7
\end{tabular}



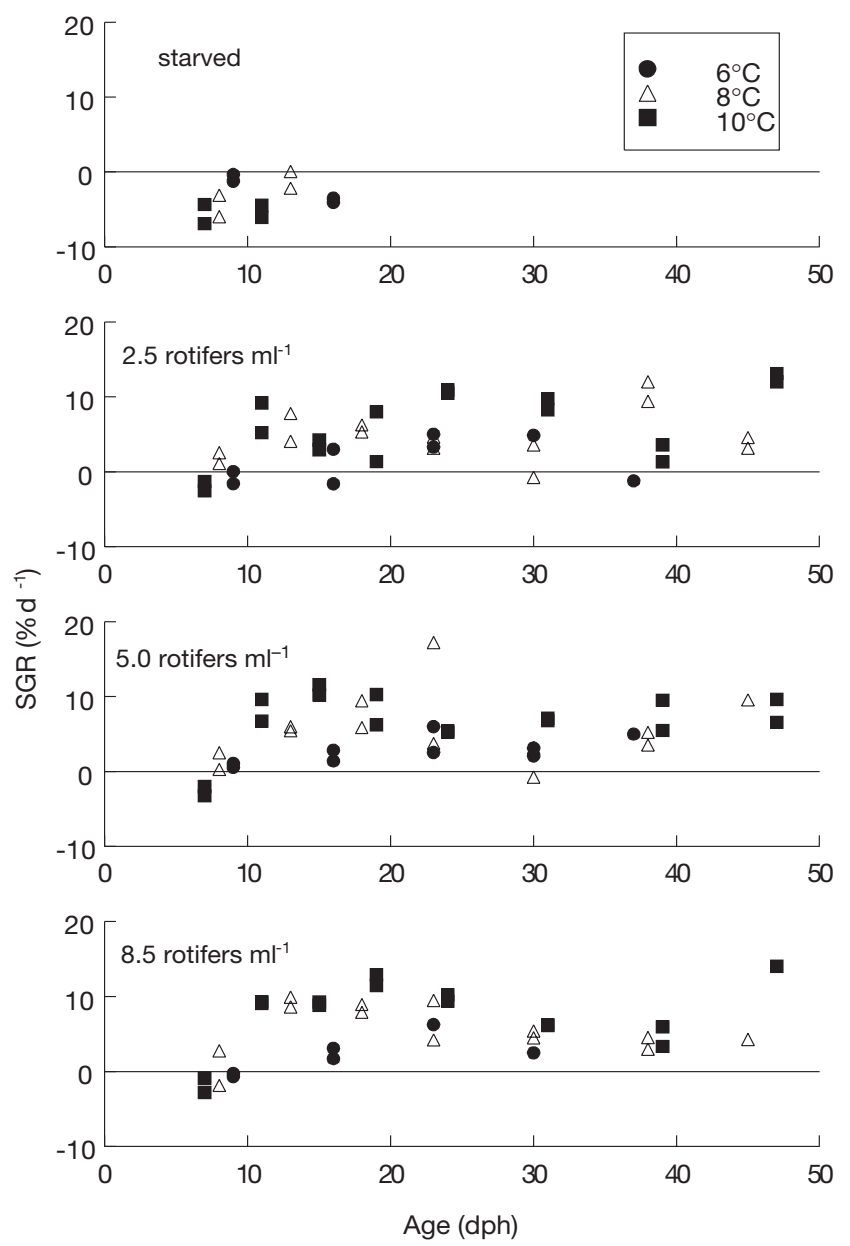

Fig. 6. Melanogrammus aeglefinus. Age-specific proteinspecific growth rate (SGR) of haddock larvae at each combination of prey concentration and temperature. Further details as in Fig. 4

estimate which encompassed a growth interval starting 2 samples previous to the R:D sample.

Using the combined cod/haddock data set, only the $\mathrm{R}: \mathrm{D}$ ratio and temperature met the significance level for entry into the model; the variable species, and the interaction of species with the R:D ratio or temperature, were not significant. The resulting SGR-R:D-temperature model can be applied to both species and was significant at the $\mathrm{p}<0.001$ level with an $\mathrm{R}^{2}=0.45$ (Table 2, Eqs. 6 \& 7).

\section{DISCUSSION}

\section{Larval growth rates}

At the highest food level, SGRs of the haddock larvae averaged $1.9,5.8$, and $9.1 \%$ protein $\mathrm{d}^{-1}$ at 6,8 , and $10^{\circ} \mathrm{C}$, respectively. These growth rates are lower than

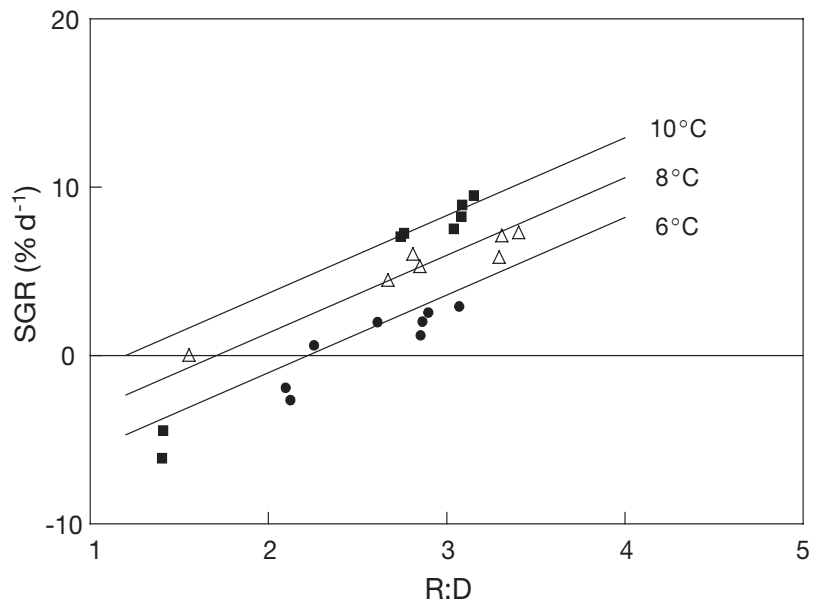

Fig. 7. Melanogrammus aeglefinus. Relationship at each rearing temperature between the tank mean RNA:DNA ratio (R:D) and protein-specific growth rate (SGR) of haddock larvae. Symbols represent the grand mean of each tank. The regression lines illustrated are predicted from Eq. (3) by substituting 6,8 , or $10^{\circ} \mathrm{C}$ as the temperature term

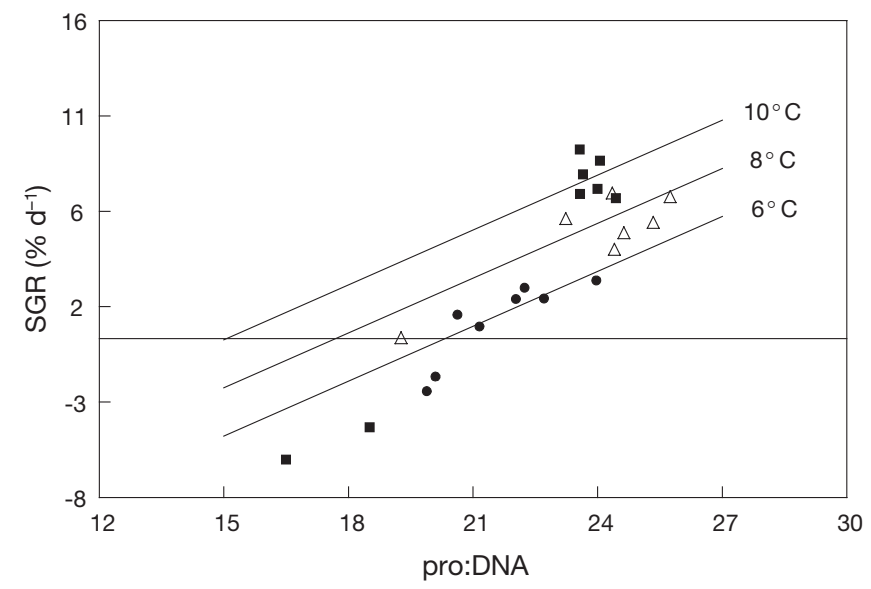

Fig. 8. Melanogrammus aeglefinus. Relationship at each rearing temperature between tank mean protein:DNA ratio (pro:DNA) and protein-specific growth rate (SGR) of haddock larvae. Symbols represent the grand mean of each tank. The regression lines illustrated are predicted from Eq. (4) by substituting 6,8 , or $10^{\circ} \mathrm{C}$ as the temperature term

those reported by Laurence (1978) for laboratoryreared haddock $\left(3.7,5.5\right.$, and $13.4 \%$ dry wt $\mathrm{d}^{-1}$ at 4,7 , and $9^{\circ} \mathrm{C}$, respectively), but in the range reported by Blair et al. (2003) (8 to $10 \%$ dry wt d $\mathrm{d}^{-1}$ at $12^{\circ} \mathrm{C}$ ). Growth rates based on protein or dry wt are comparable since the bulk of larval dry wt is comprised of protein, and the relative proportion of protein to dry wt is fairly constant during the larval period (Buckley \& Lough 1987). The initial decrease in SGRs, R:D and pro:DNA ratios observed in the fed treatments mirrors the results of the starved fish, and encompasses the time interval when 
larvae are depleting their yolk reserves and switching to exogenous food sources. Laurence $(1974,1978)$ reported complete yolk-absorption in haddock larvae at 6 to $7 \mathrm{dph}$ at $7^{\circ} \mathrm{C}$, and $6 \mathrm{dph}$ at $9^{\circ} \mathrm{C}$. The minimum R:D ratio of fed fish in the present study generally coincided with the timing of complete mortality of the starved fish at each temperature, while the pro:DNA ratio reached minimum levels 1 sampling interval earlier at the 2 higher temperatures. The fish which survived past this point began to grow as reflected in an increase in SGR, and R:D and pro:DNA ratios. This same pattern of an initial decrease in growth rates and ratios has been reported for other laboratory-reared species (Clemmesen 1987, Westerman \& Holt 1994, Caldarone et al. 2003), and probably reflects the dying-off of weaker larvae which were unable to initiate feeding, coupled with the successful establishment of exogenous feeding on the part of the survivors.

\section{Haddock model results}

There are many impediments to obtaining an accurate measure of growth in fish larvae both in captivity and in the field. Changes in length, weight, or protein content of larvae are small when measured over short time frames. Because protein sampling methods are destructive, it is necessary to estimate initial values from the mean of larvae sampled previously. This, coupled with the fact that growth rates of individuals within a treatment can be highly variable, contributes to inexact growth estimates. In a previous laboratory study with cod (Caldarone et al. 2003), an R:D-temperature model explained $\sim 30 \%$ of the variability in SGR. Growth estimates for the cod study were based on samples containing 3 to 10 individuals. The authors felt that much of the error in that model could be ascribed to errors in estimating mean growth, and that a larger sample size should improve the growth estimates. In the present study, $96 \%$ of the samples contained 15 to 30 larvae. In addition, sampling intervals were established at each temperature to correspond to similar degree days $\left(40\right.$ to $\left.42^{\circ} \mathrm{d}\right)$. For the lower 2 temperatures, this schedule lengthened the time interval between sampling to compensate for slower growth. Incorporating these 2 modifications most likely improved the growth estimates and contributed to the increased coefficient of determination of the model in the present study $\left(\mathrm{R}^{2}=0.52\right)$.

Based on the values of $R^{2}$ for the regressions predicting SGR over different time intervals, it appears that the R:D ratio was a better index of previous growth than future growth, and increasing the interval over which growth was estimated improved the relation between growth and R:D. It is likely that the accuracy of SGR estimates increases as the growth interval, and concomitant magnitude of change in protein content, increases. The generalized SGR-R:D-temperature equation formulated by Buckley (1984) with data from 8 temperate larval marine species explained $92 \%$ of the observed variance in SGR in his samples. The data input into the model consisted of a grand mean of weekly R:D and SGR values calculated over the first 3 to $17 \mathrm{wk}$ of life (depending upon the species). If in the present study 1 overall grand mean for each tank is input for the R:D ratio and SGR, the $\mathrm{R}^{2}$ of the SGR-R:Dtemperature model improves to 0.87 .

Of the many larval marine fish studies which use the R:D ratio, relatively few have accounted for the effect of temperature on RNA activity and on the ratio as a relative index of nutritional condition. Of those who have (e.g. Buckley 1982, 1984, Buckley et al. 1984, Folkvord et al. 1996, Caldarone et al. 2003), the expected relation has been observed; i.e. at a given SGR, temperature and the R:D ratio are inversely related. Therefore, 2 fish possessing identical R:D ratios but residing at different temperatures will not have the same growth rate. Because the rates of biochemical reactions increase with an increase in temperature of fish possessing the same R:D value, the fish acclimated to the warmer water will grow at a faster rate than the cold-acclimated fish. Within a narrow temperature range $\left(1\right.$ to $\left.2{ }^{\circ} \mathrm{C}\right)$, the R:D ratio from individual larval fish can be directly compared and the relative nutritional status inferred. For broader temperature ranges $\left(>2^{\circ} \mathrm{C}\right)$, the use of a growth rate model which includes both R:D ratio and temperature terms is needed.

\section{Yolk-sac/first-feeding larvae}

In both this study and a previous study with cod (Caldarone et al. 2003), the growth relationship described by temperature and the R:D or pro:DNA ratios overestimated the SGR of fish $<9 \mathrm{dph}$; therefore, those data were excluded from the final models. These results and those of Folkvord et al. (1996) indicate that growth rate-R:D-temperature models should be applied to yolk-sac/first feeding larvae with caution. Because estimates of recent growth and the relative nutritional status of these larvae are needed for both laboratory and field applications, a criteria for identifying poor-condition yolk-sac/first feeding larvae was developed. At 2 to $3 \mathrm{dph}$ at all 3 temperatures, $100 \%$ of the larvae sampled had an $\mathrm{R}: \mathrm{D}$ ratio $>2.5$ and contained 25 to $42 \mu \mathrm{g}$ protein. Of the starved larvae, $100 \%$ had an R:D ratio $<2.5$ by 16 , 8 , and $7 \mathrm{dph}$ at 6,8 , and $10^{\circ} \mathrm{C}$, respectively, and the R:D ratio continued to decrease until complete 
mortality of the groups was reached. Therefore, a starving yolk-sac haddock larva, or older larva which has been unsuccessful in feeding, can be defined as one containing $<50 \mu \mathrm{g}$ protein with an R:D ratio $<2.5$, regardless of water temperature. This criteria is identical to the one determined for yolk-sac cod larvae (Caldarone et al. 2003). In the present study, larvae held without food at the highest 2 temperatures would be classified as starving after 7 to $8 \mathrm{dph}$, while larvae reared at the lowest temperature would satisfy the criteria after $16 \mathrm{dph}$.

\section{Protein}

At all 3 temperatures, the protein content of starved larvae decreased from hatch until complete mortality was reached. This same pattern has been observed in unfed yolk-sac cod larvae; Buckley (1979) reported a $45 \%$ decrease in protein concentration between 2 and $11 \mathrm{dph}$ at $7^{\circ} \mathrm{C}$, and Caldarone et al. (2003) reported a decrease of 31,28 , and $43 \%$ between 2 and $16 \mathrm{dph}$ at 3, 6, and $9^{\circ} \mathrm{C}$, respectively. Finn et al. (1995) measured oxygen consumption, ammonia excretion, and free amino acid (FAA), lipid, protein, lactate, and $\mathrm{NH}_{4}{ }^{+}$ion concentrations of embryonic and yolk-sac stages of unfed cod larvae reared at $6^{\circ} \mathrm{C}$. They determined that during embryonic development, the primary source of metabolic fuels was FAA (75\%) followed by lipids $(37 \%)$. By hatch, the majority of the FAA had been metabolized and, when left unfed, the larvae relied on endogenous supplies of proteins and lipids for fuel. After $3 \mathrm{dph}$, they reported a steady

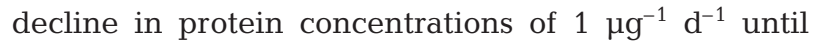
complete mortality was reached at $14 \mathrm{dph}$. It appears that unfed larval cod and haddock, even when a yolksac is still present, utilize proteins as an energy source.

\section{Pro:DNA ratio}

As is the case with the R:D ratio, it appears that the relationship between the pro:DNA ratio and larval growth is temperature-dependent. Once the pro:DNA ratio entered the model, temperature was the only other measured variable which met the significance level for entry. It is not intuitive as to why a growth model containing the pro:DNA ratio would require a temperature term since the majority of proteins are structural and, unlike RNA, are not involved in metabolic temperature-dependent activities. However, some proportion of larval proteins are enzymes whose activity is temperature-dependent, and which may contribute to the need for a temperature term.

\section{Combined haddock/cod model}

Because the nucleic acids from both haddock (this study) and cod (Caldarone et al. 2003) larvae were analyzed with identical protocols and standards, the data sets could be combined without any adjustments, and a model constructed using the combined data. A multiple regression analysis using a stepwise selection process revealed that species and the interaction of species with either the R:D ratio or temperature did not meet the significance level for entry into the model; thus, a single R:D-temperature model could be applied to both species. Haddock and cod are closely related (family Gadidae), which may have contributed to this result. It is also possible that an R:D index is not fundamentally species-specific since the biochemical pathway for protein synthesis is universal. Further interspecies comparisons of published R:D-based growth models cannot be made due to differences in nucleic acid analysis procedures between the published studies. Any deviations from a protocol (e.g. choice of standards, choice of fluorometric dyes, or UV absorption versus spectrofluorometric assays) precludes researchers from directly comparing ratios or SGR equations between laboratories (Caldarone \& Buckley 1991, McGurk \& Kusser 1992, Clemmesen 1993, Grémare \& Vétion 1994, Canino \& Caldarone 1995, Buckley et al. 1999).

Acknowledgements. I would like to thank L. M. O'Bryan, E. J. Davies, and M. A. Peck for maintaining the haddock broodstock, rearing rotifers, and collecting wild plankton. This work was supported by grants from the National Oceanic and Atmospheric Administration, and the National Science Foundation. This is US GLOBEC contribution number 246.

\section{LITERATURE CITED}

Blair T, Castell J, Neil S, D'Abramo L, Cahu C, Harmon P, Ogunmoye K (2003) Evaluation of microdiets versus live feeds on growth, survival and fatty acid composition of larval haddock (Melanogrammus aeglefinus). Aquaculture 225:451-461

Buckley LJ (1979) Relationships between RNA-DNA ratio, prey density, and growth rate in Atlantic cod (Gadus morhua) larvae. J Fish Res Board Can 36:1497-1502

Buckley LJ (1980) Changes in ribonucleic acid, deoxyribonucleic acid, and protein content during ontogenesis in winter flounder, Pseudopleuronectes americanus, and effect of starvation. Fish Bull US 77:703-708

Buckley LJ (1982) Effects of temperature on growth and biochemical composition of larval winter flounder Pseudopleuronectes americanus. Mar Ecol Prog Ser 8:181-186

Buckley LJ (1984) RNA-DNA ratio: an index of larval fish growth in the sea. Mar Biol 80:291-298

Buckley LJ, Lough RG (1987) Recent growth, biochemical composition, and prey field of larval haddock (Melanogrammus aeglefinus) and Atlantic cod (Gadus morhua) on Georges Bank. Can J Fish Aquat Sci 44:14-25 
Buckley LJ, Turner SI, Halavik TA, Smigielski AS, Drew SM, Laurence GC (1984) Effects of temperature and food availability on growth, survival, and RNA-DNA ratio of larval sand lance (Ammodytes americanus). Mar Ecol Prog Ser 15:91-97

Buckley L, Caldarone E, Ong TL (1999) RNA-DNA ratio and other nucleic acid-based indicators for growth and condition of marine fishes. Hydrobiologia 401:265-277

Buckley LJ, Caldarone EM, Lough G (2004) Optimum temperature and food-limited growth of larval Atlantic cod (Gadus morhua) and haddock (Melanogrammus aeglefinus) on Georges Bank. Fish Oceanogr 13(2):134-140

Bulow FJ (1987) RNA-DNA ratios as indicators of growth in fish: a review. In: Summerfelt RC, Hall GE (eds) The age and growth of fish. Iowa State University Press, Ames, p 45-64

Caldarone EM, Buckley LJ (1991) Quantitation of DNA and RNA in crude tissue extracts by flow injection analysis. Anal Biochem 199:137-141

Caldarone EM, Wagner M, St. Onge-Burns J, Buckley LJ (2001) Protocol and guide for estimating nucleic acids in larval fish using a fluorescence microplate reader. Ref Doc 01-11:1-22. National Marine Fisheries Service, Woods Hole, MA. Also available at: www.nefsc.noaa.gov/nefsc/ publications/crd/crd0111/crd0111.pdf

Caldarone EM, St. Onge-Burns JM, Buckley LJ (2003) Relationship of RNA/DNA ratio and temperature to growth in larvae of Atlantic cod Gadus morhua. Mar Ecol Prog Ser 262:229-240

Canino MF, Caldarone EM (1995) Modification and comparison of two fluorometric techniques for determining nucleic acid contents of fish larvae. Fish Bull US 93:158-165

Canino MF, Bailey KM, Incze LS (1991) Temporal and geographic differences in feeding and nutritional condition of walleye pollock larvae Theragra chalcogramma in Shelikof Strait, Gulf of Alaska. Mar Ecol Prog Ser 79:27-35

Chícharo MA (1997) Starvation percentages in field caught Sardina plichardus larvae off southern Portugal. Sci Mar 61(4):507-516

Chícharo MA (1998) Nutritional condition and starvation in Sardina pilchardus (L.) larvae off southern Portugal compared with some environmental factors. J Exp Mar Biol Ecol 225:123-137

Clemmesen C (1993) Improvements in the fluorimetric determination of the RNA and DNA content of individual marine fish larvae. Mar Ecol Prog Ser 100:177-183

Clemmesen CM (1987) Laboratory studies on RNA/DNA ratios of starved and fed herring (Clupea harengus) and turbot (Scophthalmus maximus) larvae. J Cons Int Explor Mer 43:122-128

Clemmesen C, Sanchez R, Wongtschowski C (1997) A regional comparison of the nutritional condition of SW Atlantic anchovy larvae, Engraulis anchoita, based on RNA/DNA ratios. Arch Fish Mar Res 45:17-43

Downing G, Litvak MK (2001) The effect of light intensity and spectrum on the incidence of first feeding by larval haddock. J Fish Biol 59:1566-1578

Esteves E, Chícharo MA, Pina T, Coelho ML, Andrade JP (2000) Comparison of RNA/DNA ratios obtained with two methods for nucleic acid quantification in gobiid larvae. J Exp Mar Biol Ecol 245:43-55

Ferron A, Leggett WC (1994) An appraisal of condition measures for marine fish larvae. Adv Mar Biol 30:217-302

Finn RN, Fyhn HJ, Evjen MS (1995) Physiological energetics of developing embryos and yolk-sac larvae of Atlantic cod (Gadus morhua). I. Respiration and nitrogen metabolism. Mar Biol 124:355-369
Folkvord A, Ystanes L, Johannessen A, Moksness E (1996) RNA:DNA ratios and growth of herring (Clupea harengus) larvae reared in mesocosms. Mar Biol 126:591-602

Grémare A, Vétion G (1994) Comparison of several spectrofluorimetric methods for measuring RNA and DNA concentrations in the deposit-feeding bivalve Abra. ovata Comp Biochem Phys 107B:2, 297-308

Henshaw EC, Hirsch CA, Morton BE, Hiatt HH (1971) Control of protein synthesis in mammalian tissues through changes in ribosome activity. J Biol Chem 246:436-446

Heyer CJ, Miller TJ, Binkowski FP, Caldarone EM, Rice JA (2001) Maternal effects as a recruitment mechanism in Lake Michigan yellow perch (Perca flavescens). Can J Fish Aquat Sci 58:1477-1487

Holm JC, Svaasand T, Wennevik V (1991) Handbook of cod culture: brood stock and fry production. Institute of Marine Research, Bergen

Houde ED (1987) Fish early life dynamics and recruitment variability. Am Fish Soc Symp 2:17-29

Houlihan DF, McCarthy ID, Carter CG, Marttin F (1995) Protein turnover and amino acid flux in fish larvae. ICES Mar Sci Symp 201:87-99

Laurence G (1974) Growth and survival of haddock (Melanogrammus aeglefinus) larvae in relation to planktonic prey concentration. J Fish Res Board Can 31:1415-1419

Laurence GC (1978) Comparative growth, respiration and delayed feeding abilities of larval cod (Gadus morhua) and haddock (Melanogrammus aeglefinus) as influenced by temperature during laboratory studies. Mar Biol 50: $1-7$

McGurk MD, Kusser WC (1992) Comparison of three methods of measuring RNA and DNA concentrations of individual Pacific herring, Clupea pallasi, larvae. Can J Fish Aquat Sci 49:967-974

Meekan MG, Fortier L (1996) Selection for fast growth during the larval life of Atlantic cod Gadus morhua on the Scotian Shelf. Mar Ecol Prog Ser 137:25-37

Peck MA, Buckley LJ, Caldarone EM, Bengtson DA (2003) Effects of food consumption and temperature on growth rate and biochemical-based indicators of growth in early juvenile Atlantic cod Gadus morhua and haddock Melanogrammus aeglefinus. Mar Ecol Prog Ser 251: 233-243

Peck MA, Buckley LJ, O'Bryan LM, Davies EJ, Lapolla AE (2004) Efficacy of egg surface disinfectants in captive spawning Atlantic cod Gadus morhua L. and haddock Melanogrammus aeglefinus L. Aquac Res 35:992-996

Rooker JR, Holt GJ (1996) Application of RNA:DNA ratios to evaluate the condition and growth of larval and juvenile red drum (Sciaenops ocellatus). Mar Freshw Res 47: $283-290$

Rooker JR, Holt GJ, Holt SA (1997) Condition of larval and juvenile red drum (Sciaenops ocellatus) from estuarine nursery habitats. Mar Biol 127:387-394

SAS Institute (1999) SAS/STAT user's guide, Version 6, 4th edn, Vol 2. SAS Institute, Cary, NC

Smith PK, Krohn RI, Hermanson GT, Mallia AK and 6 others (1985) Measurement of protein using bicinchoninic acid. Anal Biochem 150:76-85

Sutcliffe WH Jr (1970) Relationship between growth rate and ribonucleic acid concentration in some invertebrates. J Fish Res Board Can 27(3):606-609

Walsh JJ, Whitledge TE, O'Reilly JE, Phoel WC, Draxler AF (1987) Nitrogen cycling on Georges Bank and the New York Shelf: a comparison between well-mixed and seasonally stratified waters. In: Backus RH (ed) Georges Bank. MIT Press, Cambridge, MA, p 234-246 
Westerman M, Holt GJ (1994) RNA:DNA ratio during the critical period and early larval growth of the red drum Sciaenops ocellatus. Mar Biol 121:1-9

Wright DA, Martin FD (1985) The effect of starvation on RNA:DNA ratios and growth of larval striped bass,

Editorial responsibility: Kenneth Sherman (Contributing Editor), Narragansett, Rhode Island, USA
Morone saxatalis. J Fish Biol 27:479-485

Young VR (1970) The role of skeletal and cardiac muscle in the regulation of protein metabolism. In: Munro HN (ed) Mammalian protein metabolism. Academic Press, London, p 585-674

Submitted: September 7, 2004; Accepted: January 10, 2005 Proofs received from author(s): May 10, 2005 